\title{
CORRESPONDENCE.
}

\section{UNIFORM ACTION OF THE HUMAN WILL.}

\section{To the Editors of the Assurance Magazine.}

[Extract of a Letter from HERR RATH G. HoPr, of Gotha, dated 24th November, 1852.]

The last two numbers of the Assurance Magazine contain once more so many important and instructive essays, that the Editors, by publishing them, may justly be said to bave well deserved both of assurance in particular and the sciences of statistics and mixed mathematics in general. Among the most valuable contributions, I reckon the two treatises "On the Uniform Action of the Human Will," the perusal of which has afforded me so much the greater pleasure, as I soon perceived that I agreed in opinion therewith on all essentials. I besides found in them a confirmation and further exposition of what I myself had been taught by former researches. We are told of a law of mortality, and there can be no doubt that such a law exists; but in spite of the impossibility of man to struggle against it, and the narrow allowance granted him to elude it, either by a dignified mode of life or by rational precautions against sickness and injury, this law does not regulate the facts within its compass with great conformity: at least these facts, although almost independent of human will, undergo greater fluctuations than others apparently subject to its action. Among the latter are, besides the cases quoted by you, the births. The proportion which the births bear to the numbers of the population commonly is a much more uniform one than that of deaths. I some years ago collected facts in reference to this question, which, with respect to Prussia, have led me to the following results:-

In the years 1816 to 1843 , during which period the population of Prussia increased from 10 millions to $15 \frac{1}{2}$ millions, the average proportion of the births in this conntry amounted to 4.088 per cent. of the population a year, and that of the deaths to 2.886 per cent. But while the mortality of one year rose to 3.549 per cent., or exceeded by 22.95 per cent. the above stated average proportion, and that of another year lowered to 2.515 per cent., or fell short by 12.87 per cent. of the same average; the utmost fluctuations undergone by the births were between 4.487 and 3.652 per cent., or 9.77 per cent. above and 10.68 per cent. below the average proportion. The deaths, therefore, required for their fluctuations a scope of 36 per cent. of the regular ratio, whereas the births varied only 20 per cent.; and the former proved much less constant than the latter, though human will is allowed to exercise an influence on births which it cannot exercise on deaths. But this will Providence has limited by the action of instinct, the effects of which we see are far more uniform than the working of the law of mortality. Considering this, assurances for births, when established on a large scale, might be granted with greater safety than for deaths.

It is a fact, that 5 to 6 per cent. more boys than girls are born; but the cause of this fact does not seem to me to be as yet sufficiently fixed. Hofacker, a German, and Sadler, have indeed found, that from marriages up to a certain age of the married persons there will be got so much the more boys, the more the age of the husband exceeds that of the wife. When 
it is therefore considered that, at least in Germany, the husband on an average uses to be by 5 to 6 years older than his wife, this difference of age would be sufficient to make good the excess of the male births. Yet this difference of age, instead of being the true operative cause of the fact in question, is in my opinion only another parallel exterior fact, unable to account for the other. We first find that the illegitimate births show a smaller proportion of the excess of boys (in Prussia are among natural children only 103 boys to 100 girls); and yet we are not entitled to suppose the difference in the ages of the parents of natural children to differ materially from that of the parents of legitimate ones.* Another most striking abnormity occurs with the Jews, who, amounting in Prussia to about 200,000 , make at present about $1 \frac{1}{3}$ per cent. of the whole population of the kingdom of Prussia. Among this race, according to facts collected from a period of 15 years, the proportion between births of girls and births of boys being 100 to $111 \cdot 21$, the male births were prevalent in a degree probably never heard of among any other race. A large portion of the Jews, chiefly in the eastern provinces of Prussia, live in the greatest indigence; the numbers of the marriages concluded among them are less considerable than among the Christians, especially the improvident ones are much less frequent, because in all such acts the Jews do not suffer thomselves to be more operated upon by passion than guided by reason. But though, according to this statement, the proportion of the regular marriages among the Jews is a smaller one than among the Christians, such of the Jews as marry will generally enter upon wedlock in an earlier age-a circumstance which accounts for the greater fecundity of their marriages. Now it is evident that the earlier a man marries, the less in general his age will exceed that of his wife. We must therefore think ourselves justified in drawing the inference, that with the Jews the difference of age in the married persons is smaller than with the Christians; which being acknowledged, the above-mentioned excess of male births must appear still more strange, and is in no concordance whatever with the statements of Hofacker and Sadler, whose observations were limited to the Christian population. How is this abnormity to be accounted for?

There has been established an hypothesis in former times (if I am not mistaken, by the late Hoffman, of Berlin, the distinguished statist), according to which the sex of the child depends less on the difference of age in the parents, than on the predominating affection and excitement of either the father or the mother in the act of begetting. With this hypothesis agrees an old tradition of the Jews, according to which, among other purposes of the circumcision of their children, one is mentioned importing that not only cleanliness is forwarded by it, but also the procreative power strengthened, and in consequence the increase of the Jewish race promoted. If this really proved to be the case, the hypothesis in question would be supported by it; for the stronger affection, the greater excitement, would then reside with the man, and consequently effect an excess of male births.

Another fact, which remains to be considered, refers us to the same cause to account for the abnormity in question. It occurs much more

* On the contrary, I might think the age of the father in illegitimate intercourse, on average, wll surpass that of the mother more than in legitimate ones, because the average age of the mother in former is undoubtedly lower than in lattcr. 
frequently with the Jews than with the Christians, that the father disposes of his danghter in the affair of marriage, without caring for her inclination or dislike. There are, in consequence, among the Jews far more marriages in which the affection of the husband for his wife is greater than vice versa. This fact would afford a second cause why, according to the above-stated hypothesis, the male sex is so greatly prevalent among the Jewish children. As to the Christian population, the same fact, within the limits already indicated, would account also for the excess of male children among them; for love and excitement depend also, to a certain degree, on difference of age-the greater this difference between the two consorts, the greater will be the excitement of the one who has the advantage of age. The inclination of the elder part to the younger uses to be greater than vice versa ; and if, therefore, the sex of the elder predominates among the children, it is because he is under the strongest sensual affection.

This supposition being admitted, the lower proportion between the illegitimate male and female births, which is more favourable to the latter, can no longer be wondered at, when it is considered that the affection of the man, though still preponderating, cannot in this case surpass that of the woman so far as to produce the same results which proceed from regular marriages. Women undergo much more serious disadvantages in nonconnubial intercourse, and are more effectually warned against it by the whole of their social and moral situation, than men. They therefore must be under an extraordinary violence of passion before they will be led to yield to it.

Be this as it may, the facts here stated of the births among the Jews, and those taken from the jllegitimate intercourse of the two sexes, will suffice to show that the difference of age in the parents cannot in itself be the cause which effects the excess of the male births, but that this fact must be founded on deeper physiological causes, with which, however, the more advanced age of the father will frequently coincide.

The Jewish popnlation of Prussia, and probably also of other countries, exhibits still other remarkable abnormities. It being a fact, as is known, that of new-born boys a larger proportion die in the first year of life than of new-born girls (in Prussia 116.110), it ought to be presumed that, considering the predominance of boys among the Jews, the mortality of their children should be greater in the first year than among the rest of the population. Nevertheless, just the contrary takes place. In the whole kingdom of Prussia, 17.3 per cent. of the born-alive die in their first year of life; of the children of the Jews, on the contrary, only 13 per cent. Nay, what is more, the smaller proportion of mortality among the children of the Jews is to be observed on their very births, for out of all their children only 2.5 per cent. are stillborn; whereas this proportion amounts, for the whole population, to 3.51 per cent. In the same manner, also, in after life, a less high mortality seems to obtain among the Jews. In Prussia, to 100 Jews living -

$\begin{array}{cccc}\text { The Annual births were } & \text { - } & \text { - } & 3,537 \\ \text { The Annual deaths } & \text {. } & \text { - } & 2,127 \\ \text { Surplus of births } & \text { - } & \text { - } & 1,340\end{array}$

In the whole population this proportion was, according to the above statements, - 


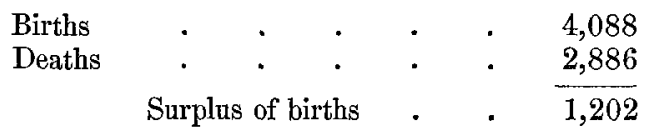

Out of 100 dying persons there were, in the whole population, $11 \cdot 71-$ among the Jews, on the contrary, 15.40-that attained an age of upwards of 70 years. More exact data are wanting.

The proportionally small numbers of the still-born and the deaths in the first year are to be declared, when one takes in consideration that Jewesses only in very rare instances perform hard work out-of-doors. They use to take great care, both of themselves during their pregnancy, and of their children while they are suckling them; whereas the majority of the Christian women, either on account of hard agricultural labour, or because they are employed in other bodily out-of-door work, are always exposed to the influence of the weather, and cannot afford to take care either of themselves or their children. The other fact, however, that a large proportion of the Jews, although they live in great poverty, and are obliged to undergo a great many privations, attain a comparatively high age, unless it be founded on deeper physiological causes, is to be accounted for by their living mostly very soberly, and by the moderate use they make, almost generally, of intoxicating liquors. On the whole, the example of the Jews may be said to show how many lives might be preserved, if a rational heedfulness of the pregnant and suckling female population, and a greater temperance in the use of brandy, became more general among the majority of the population.

Considering these facts, we are entitled to give the Jews credit for a higher vital power, or a greater toughness of life. They are therefore to be looked upon as welcome members of Life Assurance Societies. Nevertheless, I should not advise insuring them at lower rates than other persons ; I should do so, as little as I can approve of lowering the rates of assurances of women. The fact, indeed, is correct, that females in general are subject to a less high mortality than males; but not less correct and beyond doubt is the other fact, that such females as insure themselves die quicker than males. This Society has made very unfarourable experiences in this respect.

I must add, that the researches of Hofacker have been but incompletely published by Quetelet (Sur l'Homme, I., p. 55, seq.), who followed the extract of the original work contained in the Annales d'Hygiene. The former is entitled, "De qualitatibus Parentium in Sobolem prodeuntibus, presertim rei equarice. Dissertatio inauguralis med. auct. Hofacker. Tubing., 1827, 4." These researches are based upon facts, which consist of 2,000 births in the eity of Tubingen; it is to these that refer the two Tables $A$ and $B$, which I subjoin to these remarks, the former of which Quetelet has communicated but incompletely, leaving the latter altogether aside. Hofacker has extended his researches also over the rural population, but to a far more limited extent. He in this respect finds in a village, that there were born-in

43 marriages, where the wife was older than the husband, 83 boys and 103 girls;

17 marriages, where the husband was older by 9 to 12 years than the wife, 46 boys and 33 girls;

11 marriages, where the husband was 50 to 60 years old, 10 boys and 4 girls. 
In other villages he found similar proportions; and on the whole his researches lead to the conclusion that in cases where the wife is older than the husband, the proportion between the girls and boys is 1031:1000.

May these hasty communications be no unwelcome contribution to your further investigations in the science of vital statistics! A new census having been instituted in England at the end of the year 1851, the report of the General Registrar, so invariably composed with the greatest solidity and exactness, will perhaps bring forth facts tending to illustrate more particularly this strange occurrence.

A.

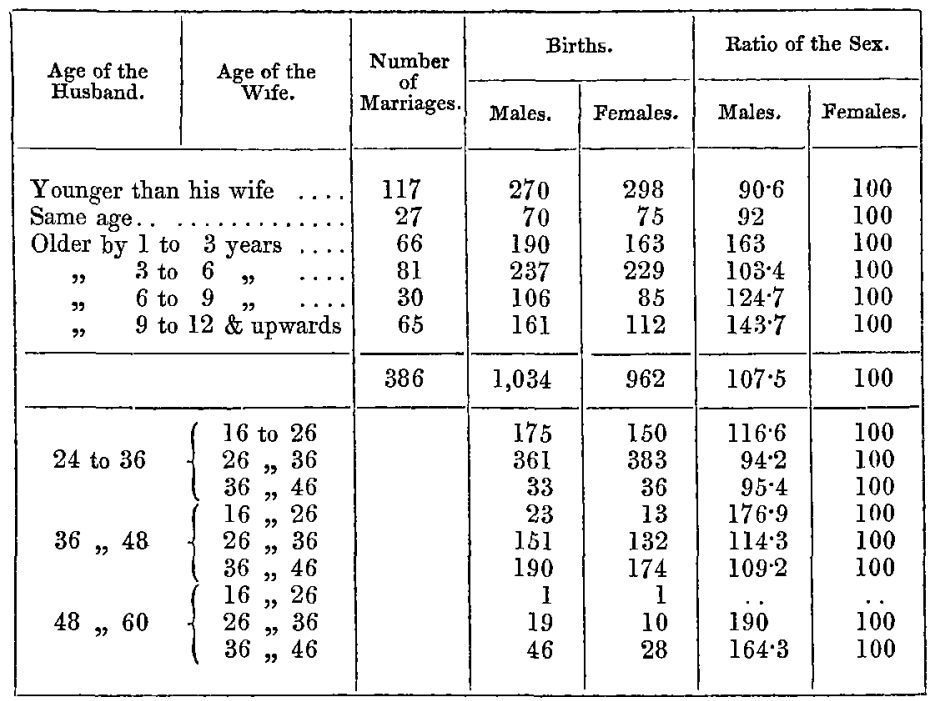

B.

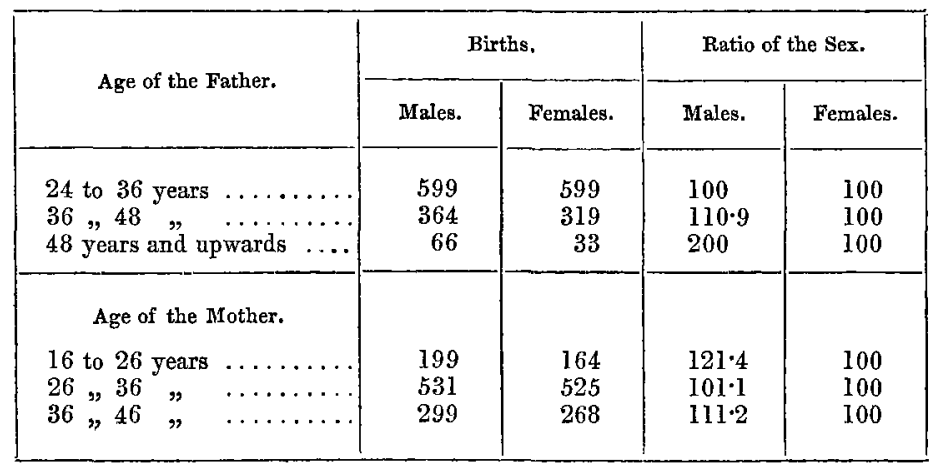

